\title{
Avaliação das pesquisas e inovações tecnológicas ocorridas na silvicultura e na produção industrial de celulose no Brasil
}

\author{
Adriana Estela Sanjuan Montebello ${ }^{1}$ \\ Carlos José Caetano Bacha
}

\begin{abstract}
Resumo: O objetivo deste trabalho é analisar a evolução das pesquisas e inovações tecnológicas ocorridas na silvicultura e na produção industrial de celulose no Brasil, dando ênfase aos seus impactos sobre a expansão dessa indústria. Para tanto, são utilizados dados primários e secundários como forma de avaliar os principais tipos de pesquisas e inovações tecnológicas e a importância dessas inovações para a expansão da indústria de celulose no Brasil e sua maior inserção no comércio mundial desse produto. Constata-se que as inovações tecnológicas nas áreas florestal e industrial trouxeram expressivos aumentos de produtividade na silvicultura e na produção industrial de celulose e foram geradas a partir de um intenso processo de interação entre empresas, universidades e governo e implicaram redução no custo de produção da celulose. Esta última elevou a rentabilidade da indústria, causando sua expansão. O trabalho encerra-se analisando os desafios futuros que a indústria de celulose no Brasil terá quanto a pesquisas e inovações visando mantê-la competitiva no cenário internacional.
\end{abstract}

Palavras-chave: celulose; pesquisa, inovação tecnológica; silvicultura.

Abstract: This paper aims to analyze the evolution of research and technological innovations that have taken in forest and pulp industrial areas, and emphasizes their possible impacts on the competitiveness of the Brazilian pulp industry. First, primary and secondary data are used to evaluate the main types of research and technological innovations and, in sequence, it is evaluated the importance of technological innovations

\footnotetext{
${ }^{1}$ Doutoranda em Economia Aplicada pela Esalq-USP. E-mail: aesanjua@esalq.usp.br

2 Professor Titular da Esalq-USP. E-mail: cjcbacha@esalq.usp.br
} 
Avaliação das pesquisas e inovações tecnológicas ocorridas na silvicultura e na produção industrial de celulose no Brasil

that have contributed to the expansion of the Brazilian pulp industry in the pulp world market. Technological innovations in forest and industrial areas in the Brazilian pulp industry have brought significant increases of forest and industrial productivities, leading to reduction of pulp production cost. Consequently, profitability of the industry has been enlarged, causing its expansion. Finally, the paper analyzes future challenges for the Brazilian pulp industry in relation to research and technological innovations able to maintain its competitiveness internationally.

Key-words: pulp; research; technological innovations; silviculture.

Classificação JEL: Q16, Q23.

\section{Introdução}

Segundo a Associação Brasileira de Celulose e Papel (Bracelpa), a produção brasileira de celulose totalizou 10,35 milhões de toneladas em 2005, o que correspondeu a 5\% do total mundial produzido de celulose. Os principais países exportadores de celulose são Canadá, Estados Unidos, Suécia, Brasil, Chile e Finlândia. Juntos, eles controlam mais de $70 \%$ das exportações mundiais. O Brasil é o 40 maior país exportador de celulose, revelando sua significativa participação no mercado mundial desse produto.

O primeiro ano de registro sistemático de exportação brasileira de celulose é o de 1961, quando foram exportadas 3,3 mil toneladas. A partir de então, essas exportações têm ampliado continuamente, atingindo 39,4 mil toneladas em 1970, 890,5 mil toneladas em 1980, 1,04 milhão de toneladas em 1990 e 5,55 milhões de toneladas em 2005 (BRASIL, 2006). Os principais países compradores da celulose brasileira são Estados Unidos, Japão, Bélgica, além dos do Reino Unido, Itália, França, Coréia e China. Conjuntamente, Estados Unidos, Japão e Bélgica lideram o ranking de maiores compradores do produto brasileiro. De 1989 a 2005, 62,03\% das exportações brasileiras de celulose, em média, foram destinadas a esses países.

Esse crescimento das exportações foi possível porque se estabeleceram empresas no Brasil que, desde a sua concepção, dedicam-se a produzir celulose de mercado ${ }^{3}$ e que atenderiam o mercado externo. Este é o caso da Celulose Nipo-Brasileira S.A. (Cenibra), Aracruz Celulose S.A. e da Veracel Celulose S.A. Outras empresas também geram excedentes para exportação, como a Suzano e a Votorantim Celulose e Papel (VCP). Além disso, as crescentes vendas externas de

${ }^{3}$ Celulose de mercado refere-se ao produto (celulose) que é vendido no mercado e não utilizado pela própria empresa produtora para elaborar papel. Difere-se da celulose de integração, que é aquela destinada diretamente pelo seu produtor para elaborar papel pela mesma empresa ou outra pertencente ao mesmo grupo.

RESR, Piracicaba, SP, vol. 47, no 02, p. 485-517, abr/jun 2009 - Impressa em julho 2009 
celulose foram determinadas pelo aumento da competitividade brasileira na produção desse produto. A celulose brasileira é totalmente elaborada a partir de madeira oriunda de florestas plantadas (o que atende às pressões ambientais) e está sendo elaborada a custos decrescentes. Isto tem estimulado as empresas situadas no Brasil a participarem no mercado externo.

É dentro desse cenário que o objetivo do presente trabalho é analisar as pesquisas e inovações tecnológicas nas áreas florestal e industrial e comentar como essas pesquisas contribuíram para a expansão da indústria brasileira de celulose.

O presente estudo está organizado em seis seções, incluindo essa introdução. A seção 2 apresenta a revisão de literatura sobre o tema em discussão, evidenciando a contribuição desse trabalho. A seção 3 apresenta o referencial analítico, a metodologia e os dados utilizados para tratar o tema em discussão. A seção 4 analisa as pesquisas e inovações tecnológicas na silvicultura e a seção 5 , as pesquisas e inovações tecnológicas na produção industrial de celulose no Brasil. Finalmente, a seção 6 apresenta as considerações finais do trabalho.

\section{Revisão de literatura}

Há alguns trabalhos analisando a indústria de celulose no Brasil e as pesquisas silviculturais e industriais associadas à produção de celulose. Esses estudos podem ser agregados nos seguintes grupos: a) trabalhos analisando a organização da indústria (Pizzol \& Bacha, 1998; Silva, 2000); b) trabalhos analisando o papel das políticas públicas em estimular a indústria de celulose no Brasil (Hilgemberg \& Bacha, 2001; e Silva, 1996); c) estudos sobre a importância do setor florestal na geração do PIB e de empregos (ABIMCI, 2004); d) trabalhos sobre a competitividade da indústria (Sanjuan e Bacha, 2003; e Jorge, 2001); e) principais demandas públicas e privadas na pesquisa florestal; f) trabalhos sobre demanda e fonte de recursos para pesquisa no setor florestal; e g) trabalhos sobre a tecnologia e inovação tecnológica na indústria de celulose brasileira. Esses três últimos grupos são analisados com mais detalhes a seguir.

O estudo do Ministério da Ciência e Tecnologia - MCT (BRASIL, 2002) traz as principais demandas públicas e privadas em termos de pesquisa na área de tecnologia de celulose e papel. Estas demandas são divididas nos seguintes itens: (1) novas ferramentas analíticas para avaliação de parâmetros de qualidade da madeira, de forma a permitir a avaliação de um maior número de materiais em reduzido espaço de tempo; (2) desenvolvimento de sistemas de simulação de processos modificados de polpação e branqueamento - modelagem matemática; (3) processos de polpação e branqueamento para fibras longas oriundas de florestas plantadas no Brasil; (4) desenvolvimento/modificação de processos visando a superação da barreira do rendimento; (5) utilização da biotecnologia em processos de polpação e branqueamento de polpa celulósica, tais como o 
desenvolvimento e utilização de enzimas; (6) morfologia de fibras e sua relação com a silvicultura e características de polpa e papel; (7) genômica funcional aplicada à celulose e papel; (8) desenvolvimento de tecnologias de polpação e branqueamento para recursos fibrosos não-convencionais; (9) fechamento de circuitos - redução/eliminação de emissões ambientais.

Com relação às fontes de recursos públicos e privados para a pesquisa no setor florestal brasileiro, o trabalho do MCT (BRASIL, 2002) concluiu que 54 organizações contribuíram para a pesquisa e desenvolvimento em ciência, tecnologia e inovação. $O$ trabalho ressalta que apesar da maior parte da produção científica florestal no Brasil ser gerada por pesquisadores ligados às Universidades, à Embrapa e por poucos institutos de pesquisa especializados, há notável produção científica de dezesseis empresas de base florestal.

Segundo BRASIL (2002), as fontes de recursos destinados à pesquisa em processamento químico, que abrange celulose e papel, carvão, resinas e óleos essenciais, são oriundas quase que exclusivamente do setor público. Os recursos do setor público são disponibilizados por agências de fomento à pesquisa tais como o Conselho Nacional de Desenvolvimento Científico e Tecnológico (CNPq), Financiadora de Estudos e projetos (Finep), Ministério da Ciência e Tecnologia (MCT), Fundação de Amparo à Pesquisa do Estado de São Paulo (Fapesp), Fundação de Amparo à Pesquisa do Estado de Minas Gerais (Fapemig), entre outras.

Analisando a tecnologia usada no Brasil pela indústria de celulose, tem-se o trabalho de Barrichello (2005) que destaca que toda tecnologia empregada no Brasil na área de produção de celulose, até 1950, era importada do exterior, em especial dos Estados Unidos e da Europa. Com o despertar da possibilidade de utilização do eucalipto como uma matéria-prima de grande potencialidade, as indústrias passaram a desenvolver pesquisas em paralelo à consolidação de associações como a Associação Brasileira Técnica de Celulose e Papel (ABTCP), fundada em 1967, e institutos como o Instituto de Pesquisas e Estudos Florestais (Ipef) passaram a promover sinergismos e aproximações em busca de uma tecnologia adaptada à realidade brasileira.

Outra bibliografia, em relação a esse tema de tecnologia e inovação tecnológica, engloba os estudos genômicos considerados significativos para o setor de celulose e papel. O projeto Genolyptus, desenvolvido pelos laboratórios da Klabin, permite consolidar a liderança do País na produção de fibras de eucalipto e permite que a indústria nacional concorra com os experimentos realizados por laboratórios estrangeiros. Tal projeto, por meio de mapeamento genético, possibilita desenvolver espécies de eucalipto propícias para cada região, como as que são resistentes à geada, ao solo mais arenoso ou a reduções de índices pluviométricos, por exemplo. Dessa maneira, essa experiência reflete uma forma de agregar valor ao setor e ampliar a competitividade brasileira no mercado internacional de papel e celulose (PARA EMPRESÁRIOS..., 2002). 
Faz-se necessário ressaltar que a literatura acima mencionada não mostrou como as políticas públicas afetaram as atividades de pesquisas ocorridas na silvicultura brasileira. Além disso, não foram mencionadas como essas pesquisas se materializaram em inovações tecnológicas e como essas inovações, ocorridas na silvicultura e na produção industrial de celulose, contribuíram para a expansão do setor. Sendo assim, este trabalho irá contribuir para compreender mais detalhadamente esses processos.

\section{Referencial analítico, metodologia e dados utilizados}

Entre os modelos de análise da geração de tecnologia na agropecuária destaca-se o de De Janvry (1978), o qual analisa o papel que grupos de interesses têm em pressionar instituições públicas para desenvolverem pesquisas que lhes dão maiores retornos esperados. No caso da silvicultura brasileira, as empresas consumidoras de madeira aliaram-se com os centros de pesquisas e universidades e pressionaram por pesquisas que gerassem retornos efetivos a partir de uma matriz ex-ante de retornos esperados. Essas pesquisas visaram, basicamente, reduzir o custo de obtenção da madeira, fazendo do país um dos mais competitivos na produção de celulose.

Há no Brasil uma grande parceria universidade pública-empresa, da qual o Instituto de Pesquisas Florestais (Ipef), na Esalq/USP, e a Sociedade de Investigações Florestais (SIF), na Universidade Federal de Viçosa, são grandes exemplos. De acordo com Labate (2005), a parceria universidade pública-empresa é o grande diferencial para o futuro dos estudos científicos no Brasil, colocando o país em vantagem no cenário mundial de produção e comércio do produto. $\mathrm{O}$ autor destaca que no caso do departamento de genética da Escola Superior de Agricultura "Luiz de Queiroz" da Universidade de São Paulo (Esalq/USP), a parceria com a iniciativa privada possibilitou um fluxo de recursos constante para o desenvolvimento de pesquisas dentro da universidade. A parceria com a Companhia Suzano de Papel e Celulose teve início em 1998 com o primeiro projeto para desenvolver um método de transformação genética do eucalipto. Ao final desse projeto, segundo Labate (2005), foram obtidas as primeiras plantas transgênicas de eucalipto, além da formação de vários alunos e técnicos ligados à pesquisa. Os bons resultados trazidos com esse projeto estimularam um novo trabalho, no ano 2000, entre a Universidade de São Paulo e a Suzano, sendo estabelecido um estudo para a clonagem de vários genes de eucalipto e outros compostos de interesse à qualidade da madeira. 
Avaliação das pesquisas e inovações tecnológicas ocorridas na silvicultura e na produção industrial de celulose no Brasil

Conforme estudo divulgado nos relatórios anuais das empresas de celulose e papel é evidente que, a partir de 2000, vem ocorrendo forte integração entre universidades públicas e empresas. De acordo com o Relatório Anual de Sustentabilidade da Votorantim (2007), a empresa oferece curso de pós-graduação em tecnologia de celulose e papel, feito em parceria com a Universidade Federal de Viçosa, sendo este curso destinado aos profissionais que buscam formação na produção de celulose e papel. De 2000 a 2007, 32 profissionais das áreas industrial, florestal e de engenharia passaram pelo curso. Outro exemplo de integração entre as universidades e empresas, prática que vem se difundindo nos anos recentes, é mostrado pelas pesquisas realizadas pela Aracruz em parceria com universidades públicas como a Universidade Federal de Lavras e a Universidade Federal de Viçosa. Segundo o Relatório Anual da Aracruz (2007), a empresa - por meio da parceria com a Universidade Federal de Lavras - vem realizando importante estudo envolvendo o mapeamento do solo das áreas em expansão, além de medições relevantes sobre a erosão potencial e o monitoramento do impacto dos equipamentos de colheita. Além disso, na área de manejo integrado de pragas e doenças, foram conduzidas, em 2007, várias pesquisas integrando as áreas de melhoramento genético e de proteção florestal em parceria com a Universidade Federal de Viçosa.

Para o setor industrial, a literatura distingue modelos de geração versus modelos de difusão de tecnologia, inovações de processo versus inovações de produto, pequenas versus grandes inovações e diagnostica a existência de pacotes tecnológicos (Cruz, 1988). Há modelos que explicam as forças que levam à geração de tecnologia, e outros que explicam como dada tecnologia difunde-se entre os produtores. As inovações podem ser classificadas em grandes ou pequenas de acordo com o desvio que provocam em relação ao paradigma existente. As inovações de processo alteram o modo de produzir um bem, e as inovações de produto implicam surgimento de novos bens. Segundo Sabato \& Mackenzie (1981, p. 10-11), pacote tecnológico é um conjunto "de conhecimentos organizados de diferentes tipos (científico, empírico etc.), provenientes de várias fontes (descobertas científicas, outras tecnologias, patentes, livros, manuais etc.), através de diferentes métodos (pesquisa, desenvolvimento, adaptação, reprodução, espionagem, especialistas etc.)".

No caso do Brasil, a tecnologia de produção de celulose é importada (adota-se o pacote tecnológico desenvolvido em outros países) e o que o País gerou foi sua adaptação para o uso do eucalipto. A maior comprovação de que a tecnologia é importada é que os equipamentos são importados ou produzidos no Brasil por empresas estrangeiras (Valença, 2001). 
O presente artigo procura ilustrar que tipos de inovações tecnológicas ocorreram na silvicultura e na etapa industrial, o que permitirá associá-las, nas conclusões, com os modelos supracitados.

Através da revisão de literatura é possível diagnosticar as etapas da silvicultura e da produção industrial que receberam, ao longo do tempo, maior atenção das pesquisas. A periodicidade utilizada é das décadas de 80, 90 e 2000. Para avaliar como essas pesquisas se transformaram em inovações tecnológicas e a importância dessas inovações, foram enviados via correio eletrônico questionários ${ }^{4}$ a especialistas nas etapas florestal e industrial da produção de celulose. A amostra dessa pesquisa é composta por professores universitários da Esalq/USP, Universidade Federal de Santa Maria, Universidade Federal de Pernambuco, Universidade Federal de Viçosa, Universidade Federal do Paraná, além de pesquisadores da área de estudo e empresas do setor de celulose e papel. Do total de 76 questionários submetidos aos especialistas da área florestal, foram obtidas 19 respostas, sendo que foram totalizadas 16 respostas nas etapas de mecanização e sistemas computacionais e 17 respostas nas demais etapas. No caso da área industrial, do total de 43 questionários enviados às indústrias e pesquisadores dessa área foram obtidas 15 respostas, sendo totalizadas 11 repostas nas seguintes etapas: qualidade da polpa, matriz energética, desenvolvimento de produtos e genômica e OGMS. Nas demais etapas foram computadas 13 respostas. Segundo Gil (1991), para esta técnica de pesquisa (questionário enviado pelo correio, incluindo e-mail) não se consegue mais do que 20 ou $25 \%$ de devoluções. Nossa pesquisa ficou no limite superior de devolução de questionários.

Para testar se as inovações tecnológicas referentes às áreas florestal e industrial diferem entre as décadas de 1980, 1990 e os anos 2000, foi utilizado o teste não paramétrico de Wilcoxon ${ }^{5}$, que é indicado quando as variáveis são medidas em escala ordinal. Esse teste permite verificar se, em média, o grau de relevância atribuído à determinada inovação difere estatisticamente de uma década a outra. Os testes não paramétricos não exigem a normalidade dos dados, tampouco a homogeneidade das variâncias dos tratamentos. O software utilizado para o cálculo do teste não paramétrico de Wilcoxon foi o SPSS na versão 12.0.

${ }^{4}$ Enviaram-se aos entrevistados os Quadros 1 e 2 para que os mesmos preenchessem com $X$ a resposta a cada item especificado na primeira coluna.

${ }^{5} \mathrm{O}$ teste das ordens assinaladas de Wilcoxon (Wilcoxon signed rank test) permite verificar se a diferença de valores de um par de observações - por exemplo (Xi, Yi), onde Xi é o valor da classsificação de uma inovação tecnológica na década de 1980 e Yi é o valor da classificação dessa mesma inovação na década de 1990 pelo mesmo respondente são estatisticamente significativas ou não. Utiliza-se nesse trabalho o cálculo de $T^{*}$ para o caso de haver empate no valor das diferenças (CAMPOS, 1979, p. 94-95). 
Os questionários indagam ao entrevistado, para cada período, se um tipo específico de inovação (identificado pela etapa do processo de produção) implicou em inovação tecnológica pouco relevante, relevante ou muito relevante. Para permitir o uso do teste de Wilcoxon, o valor 1 foi atribuído à resposta que indica uma certa inovação tecnológica ser pouco relevante, o valor 2 para o caso dela ser relevante e o valor 3 para o caso de ser muito relevante.

Os dados secundários foram coletados por meio da análise de estudos técnicos e informativos disponíveis na literatura sobre pesquisa e inovação silvicultural e industrial na cadeia produtiva de celulose. Esses dados são apresentados na forma de tabelas e gráficos.

\section{Pesquisas e inovações tecnológicas na silvicultura}

Esta seção analisa a evolução das pesquisas e inovações tecnológicas ocorridas na silvicultura. Pretende-se mostrar os principais tipos e a importância das inovações tecnológicas que contribuíram para a maior competitividade e conseqüente expansão da indústria de celulose brasileira e sua maior inserção no comércio mundial desse produto.

\subsection{Evolução das pesquisas e inovações tecnológicas na silvicultura ${ }^{6}$}

Segundo Antonangelo e Bacha (1998a), a evolução da silvicultura brasileira apresenta três etapas. A primeira correspondeu ao período que vai do descobrimento do Brasil até o início dos incentivos fiscais ao reflorestamento/ florestamento em 1965. A segunda fase abrange o período de vigência dos incentivos fiscais ao reflorestamento/florestamento (de 1966 a 1988). A terceira fase cobre o período pós-incentivos fiscais ao reflorestamento/florestamento (de 1989 até hoje). Essa mesma divisão pode ser utilizada para tratar dos tipos de pesquisas silviculturais realizadas.

Na primeira fase, os estudos na silvicultura brasileira concentraram-se na área de manejo, sendo que esse tipo de pesquisa predominou até o final da década de 1960. Até o ano de 1961, segundo o Ministério da Ciência e Tecnologia (BRASIL, 2002), não havia nenhuma escola especializada no ensino florestal no País. As disciplinas relacionadas com a silvicultura e a tecnologia da madeira eram ministradas nas escolas de agronomia e engenharia. A formação de mão-de-obra especializada no País foi determinada pela necessidade de dar suporte técnico ao desenvolvimento da atividade produtiva do setor florestal.

${ }^{6}$ Este item baseia-se em Antonangelo e Bacha (1998b) e em Brasil (2002) que analisaram os trabalhos publicados em revistas científicas e que sumarizam as pesquisas e inovações feitas na silvicultura. A relevância das inovações é tratada no subitem seguinte. 
Com o surgimento da política de incentivos fiscais para o reflorestamento ${ }^{7}$, vigente de 1966 a 1988, o setor florestal brasileiro pôde ampliar o seu nível tecnológico, adentrando-se na segunda fase da evolução da silvicultura. Criaram-se nesse período, conforme Foelkel (2003), inúmeros cursos técnicos e universitários em Engenharia Florestal, surgiram institutos de pesquisa com programas cooperativos de pesquisa e desenvolvimento e formaram-se técnicos competentes e pró-ativos. Destaca-se que, entre fins dos anos 60 e início dos anos 70, surgiram os cursos de pós-graduação em florestas e em celulose e papel na Universidade de São Paulo e na Universidade Federal de Viçosa. Vale ressaltar que a Embrapa criou seu órgão de pesquisa florestal em Colombo (PR), o antigo Centro Nacional de Pesquisa de Florestas, atual Embrapa Florestal, com forte ênfase em programas agroflorestais e em manejo de florestas nativas.

Evidenciam-se, ainda nesse período, as inovações tecnológicas na área de melhoramento genético. Conforme Antonangelo e Bacha (1998b), no final da década de 1970, esses avanços podem ser classificados como inovações tecnológicas biológicas, tanto de produto (pois novas espécies foram introduzidas), quanto de processo (novos métodos para escolha de espécies, como testes de procedência) grandes (pois provocaram grandes aumentos de produtividade) e nacionais.

Na década de 1980, alavancou, nessa área de melhoramento genético, o uso de métodos de clonagem e os testes de progênies (seleção de melhores indivíduos gerados a partir de um cruzamento específico). Ainda, nessa década, vale considerar os saltos tecnológicos na área de produção de mudas por semeadura direta em embalagens e na área de adubação por meio de métodos relacionados à calagem e à gessagem. Além disso, novos elementos químicos foram utilizados, os quais trouxeram grandes aumentos de produtividade (ANTONANGELO; BACHA, 1998b).

Ainda na década de 1980, segundo BRASIL (2002), surgiram algumas contribuições na área de qualidade da madeira, sendo desenvolvidos trabalhos visando a definição de parâmetros para essa qualidade, sendo os resultados desses trabalhos úteis para a área de melhoramento genético florestal e para o processamento industrial da madeira, ferramentas chaves para ganhos de produtividade.

De acordo com os dados da Tabela 1, a qual traz os trabalhos produzidos nas áreas de ambiência, manejo florestal, silvicultura e tecnologia de produtos florestais, durante a década de 1980, a produção científica totalizou 367 trabalhos, sendo que as regiões Sul e Sudeste concentraram 75\% desse total. Do total de trabalhos, 66,5\%

7 Os incentivos fiscais ao reflorestamento foram, pela primeira vez, previstos em legislação de 1965, mas foram iniciados em 1966 e concedidos até 1986. Nos dois anos seguintes, houve liberações para projetos já aprovados. 
494 - Avaliação das pesquisas e inovações tecnológicas ocorridas na silvicultura e na produção industrial de celulose no Brasil

concentraram-se nos temas de manejo florestal e silvicultura. Também pode ser observado, conforme BRASIL (2002), que durante a década de 1980 foi pequena a freqüência de trabalhos florestais publicados na área de ambiência (em torno de $12 \%$ do total). Os aspectos ambientais, e a sua relação com as atividades florestais, somente começaram a ter maior divulgação nas décadas seguintes.

Tabela 1. Artigos sobre silvicultura nas publicações nacionais segundo a região a que se refere o estudo (1980 - 2002)

\begin{tabular}{|c|c|c|c|c|}
\hline \multirow{2}{*}{ Região } & \multirow{2}{*}{ Tema } & \multicolumn{3}{|c|}{ Produção científica } \\
\hline & & 1980-89 & 1990-99 & 2000-2002 \\
\hline \multirow{4}{*}{$\begin{array}{c}\text { Abrangência } \\
\text { Nacional }\end{array}$} & Ambiência & 1 & 6 & 3 \\
\hline & Manejo Florestal & 5 & 23 & 18 \\
\hline & Silvicultura & 19 & 19 & 14 \\
\hline & Tecnologia de Produtos Florestais & 9 & 3 & 4 \\
\hline \multirow{4}{*}{ Centro Oeste } & Ambiência & 2 & 4 & 0 \\
\hline & Manejo Florestal & 4 & 12 & 5 \\
\hline & Silvicultura & 4 & 7 & 2 \\
\hline & Tecnologia de Produtos Florestais & 0 & 3 & 3 \\
\hline \multirow{4}{*}{ Norte } & Ambiência & 11 & 13 & 6 \\
\hline & Manejo Florestal & 12 & 7 & 4 \\
\hline & Silvicultura & 16 & 18 & 4 \\
\hline & Tecnologia de Produtos Florestais & 8 & 5 & 0 \\
\hline \multirow{4}{*}{ Nordeste } & Ambiência & 0 & 4 & 0 \\
\hline & Manejo Florestal & 0 & 11 & 1 \\
\hline & Silvicultura & 0 & 4 & 1 \\
\hline & Tecnologia de Produtos Florestais & 1 & 5 & 3 \\
\hline \multirow{4}{*}{ Sul } & Ambiência & 13 & 11 & 1 \\
\hline & Manejo Florestal & 35 & 43 & 3 \\
\hline & Silvicultura & 22 & 32 & 6 \\
\hline & Tecnologia de Produtos Florestais & 14 & 15 & 7 \\
\hline \multirow{4}{*}{ Sudeste } & Ambiência & 17 & 15 & 4 \\
\hline & Manejo Florestal & 54 & 92 & 8 \\
\hline & Silvicultura & 73 & 88 & 12 \\
\hline & Tecnologia de Produtos Florestais & 47 & 23 & 8 \\
\hline Total & & 367 & 463 & 117 \\
\hline
\end{tabular}

Nota: Os artigos publicados por instituições de pesquisa não identificadas com uma única região foram caracterizados como de "Abrangência Nacional".

Fonte: Adaptado de Brasil (2002) 
Com o fim dos incentivos fiscais ao reflorestamento/florestamento, em especial a partir de 1989, uma nova tendência na evolução tecnológica da silvicultura brasileira surgiu. Antonangelo e Bacha (1998b) relatam que, a partir do final da década de 1980, houve uma melhor distribuição dos trabalhos entre todas as áreas de pesquisa (manejo, melhoramento genético, produção de mudas, controle de pragas e doenças, adubação, mecanização e controle gerencial). Além dessa melhor distribuição dos trabalhos, teve início também uma maior preocupação com pesquisas que proporcionem eficiência, isto é, a diminuição de custos, aumento da produtividade, maior qualidade e maior competitividade. Ergueu-se também a bandeira de alerta em relação às questões ecológicas. Assim, os estudos voltaram-se um pouco mais para as espécies nativas, que, contrariamente ao grande desenvolvimento da pesquisa sobre pinus e eucalipto verificado na silvicultura brasileira nestes últimos trinta anos, foram pouco enfocados até então.

De acordo com a Tabela 1, a produção científica aumentou de 367 trabalhos na década de 1980 para 463 trabalhos na década seguinte (aumento de 26\%). Além disso, a concentração de trabalhos nas áreas de silvicultura e manejo florestal aumentou de 66,5\%, na década de 1980, para 77\% nos anos 1990. Além disso, houve melhoria na distribuição regional da produção científica, com os trabalhos referentes às regióes Sul e Sudeste passando a contribuir com uma participação menor do total de trabalhos publicados (69\% na década de 1990, contra $75 \%$ na década de 1980 ).

De 2000 a 2002, conforme a Tabela 1, há um equilíbrio regional maior na produção de ciência, tecnologia e inovação na silvicultura, tornando a participação dos trabalhos referentes às regiões Sul e Sudeste inferior à metade (42\%) e concentrando as demais regiões um percentual de $58 \%$ da produção total.

Nos últimos anos, diversas conquistas foram sendo obtidas na área florestal. Alguns exemplos são as novas técnicas computacionais, matemáticas e estatísticas desenvolvidas para melhorar a gestão florestal, a partir do manejo sustentável. Conforme Savastano (2001) destacam-se, nesta fase mais atual, projetos de melhoramento genético do eucalipto, cujo objetivo consiste em mapear os principais genes do eucalipto a fim de aumentar a produtividade. Entre esses projetos estão: o Projeto Genolyptus, lançado em fevereiro de 2002, com o intuito de aumentar a produtividade da indústria brasileira de celulose e papel; e o projeto genoma eucalipto Forests, cujo objetivo consistiu em identificar 15.000 genes preparados de diferentes tecidos, incluindo plântulas, folhas, raízes, caule e madeira, a fim de aumentar tanto a eficiência da produção madeireira como a qualidade dos produtos.

Cruz (2001) afirma que a tecnologia florestal brasileira já pode ser considerada consolidada, uma vez que o desenvolvimento genético alcançado para o eucalipto permite o corte para industrialização aos sete anos, com alta 
496 - Avaliação das pesquisas e inovações tecnológicas ocorridas na silvicultura e na produção industrial de celulose no Brasil

produtividade, enquanto as florestas boreais do hemisfério norte têm um ciclo de no mínimo trinta anos, sendo que, usualmente, cortam-se matas nativas.

Ainda nos últimos anos, pode-se evidenciar que o Brasil possui o maior banco de germoplasma do gênero Eucalyptus e de algumas espécies de Pinus. Segundo Leite (2005), esse contexto científico e tecnológico possibilitou expressivos e significativos aumentos na produtividade das florestas plantadas. É importante destacar também, conforme o estudo realizado por Leite (2005), que atualmente os procedimentos operacionais da silvicultura estão voltados para os seguintes temas: planejamento sócio-ambiental criterioso; sementes e clones selecionados; controle nutricional; técnicas altamente eficazes de manejo, proteção e colheita.

Com respeito ao processo de mecanização das operações realizadas na silvicultura, o qual foi intensificado na década de 1990, é importante destacar que esse processo vem procurando melhorar as práticas da colheita florestal, além de procurar minimizar o impacto da utilização de máquinas no meio ambiente. De acordo com Seixas (2005), a preocupação com a compactação do solo levou ao desenvolvimento de máquinas, cujos atrativos são a redução da área impactada, maior adaptabilidade a condições adversas do terreno, superação de obstáculos, boa dirigibilidade e maior conforto para o operador.

$\mathrm{Na}$ busca por mercados internacionais, outro instrumento positivo para diferenciar a produção brasileira de celulose e papel e inseri-la nos padrões mundiais foi a criação do esquema de certificação florestal, tal como o Forest Stewardship Council (FSC). O Brasil apresenta o maior número de florestas certificadas pelo FSC da América Latina. Até janeiro de 2006, o número de florestas certificadas pela Brasil totalizou 3.532.154 florestas, o que correspondeu a 44,18\% do total de florestas certificadas na América Latina pelo FSC. Além disso, o país ultrapassou a Bolívia, que detém 2,04 milhões de florestas certificadas (25,55\% do total). Essa colocação foi possível porque as empresas de celulose e papel aumentaram significativamente a área certificada nos últimos anos. De acordo com os dados do FSC, elas representaram 32,07\% do total de florestas certificadas pelo FSC no Brasil em início de 2006, enquanto em 2001 essa importância era de 8,3\% e inexistente em 2000. Vale destacar que o Brasil ocupa o sexto lugar no ranking mundial de área florestal certificada, ficando atrás do Canadá, Suécia, Rússia, EUA e Polônia.

Além do FSC, que opera no Brasil desde 1995, segundo Garlipp (2005a), o Brasil desenvolveu o sistema de Certificação Florestal (Cerflor), gerido pelo Instituto Nacional de Metrologia e Qualidade Industrial (Inmetro), o qual começou a operar em 2003. Faz-se necessário destacar que o Cerflor está em processo de reconhecimento internacional pelo Programa para o Reconhecimento de Certificação Florestal (PEFC), o maior sistema mundial de certificação de florestas. 


\subsection{Importância das inovações tecnológicas na silvicultura}

Os trabalhos até agora analisados, em especial o de Antonangelo e Bacha (1998b) e Brasil (2002), referem-se aos tipos de pesquisas realizadas e sua intensidade. Não há, ainda, uma avaliação da relevância dessas pesquisas em termos das inovações que geraram. De modo a ter essa avaliação, foram elaborados os questionários, enviados via e-mail, no período de abril a novembro de 2006, a reconhecidos especialistas nas áreas de silvicultura e indústria de celulose.

Foram respondidos 19 questionários na área de silvicultura. As etapas avaliadas nessa área foram: melhoramento genético, produção de mudas, manejo florestal, proteção florestal, controle de qualidade, mecanização e sistemas computacionais. Perguntou-se aos entrevistados se cada uma dessas etapas gerou inovações tecnológicas pouco relevantes, relevantes ou muito relevantes em cada período analisado (décadas de 80 e 90 e anos 2000). A distribuição percentual das respostas está no Quadro 1.

Na década de 1980, o melhoramento genético tradicional e a produção de mudas via sexuada foram as etapas mais bem pontuadas entre as que tiveram inovações tecnológicas. Das 19 pessoas entrevistadas, 68,42\% e 57,89\% classificaram as inovações tecnológicas nessas duas etapas da silvicultura como muito relevantes, respectivamente. Já a produção de mudas via clonagem não foi uma inovação tecnológica que se destacou na década de 1980. Em relação aos recipientes e substratos para a produção de mudas, notou-se que $47,37 \%$ e $63,16 \%$, respectivamente, dos entrevistados consideraram as inovações nessas atividades como sendo relevantes na década de 80 . Todos os itens de manejo florestal e proteção florestal tiveram inovações importantes na década de 80. Já na etapa mecanização, as inovações tecnológicas nos itens implantação e colheita foram relevantes para o período considerado. Contudo, a disponibilidade, produtividade ou capacidade das máquinas e seu impacto no meio ambiente não apresentaram inovações significativas nesse período. 
498 - Avaliação das pesquisas e inovações tecnológicas ocorridas na silvicultura e na produção industrial de celulose no Brasil

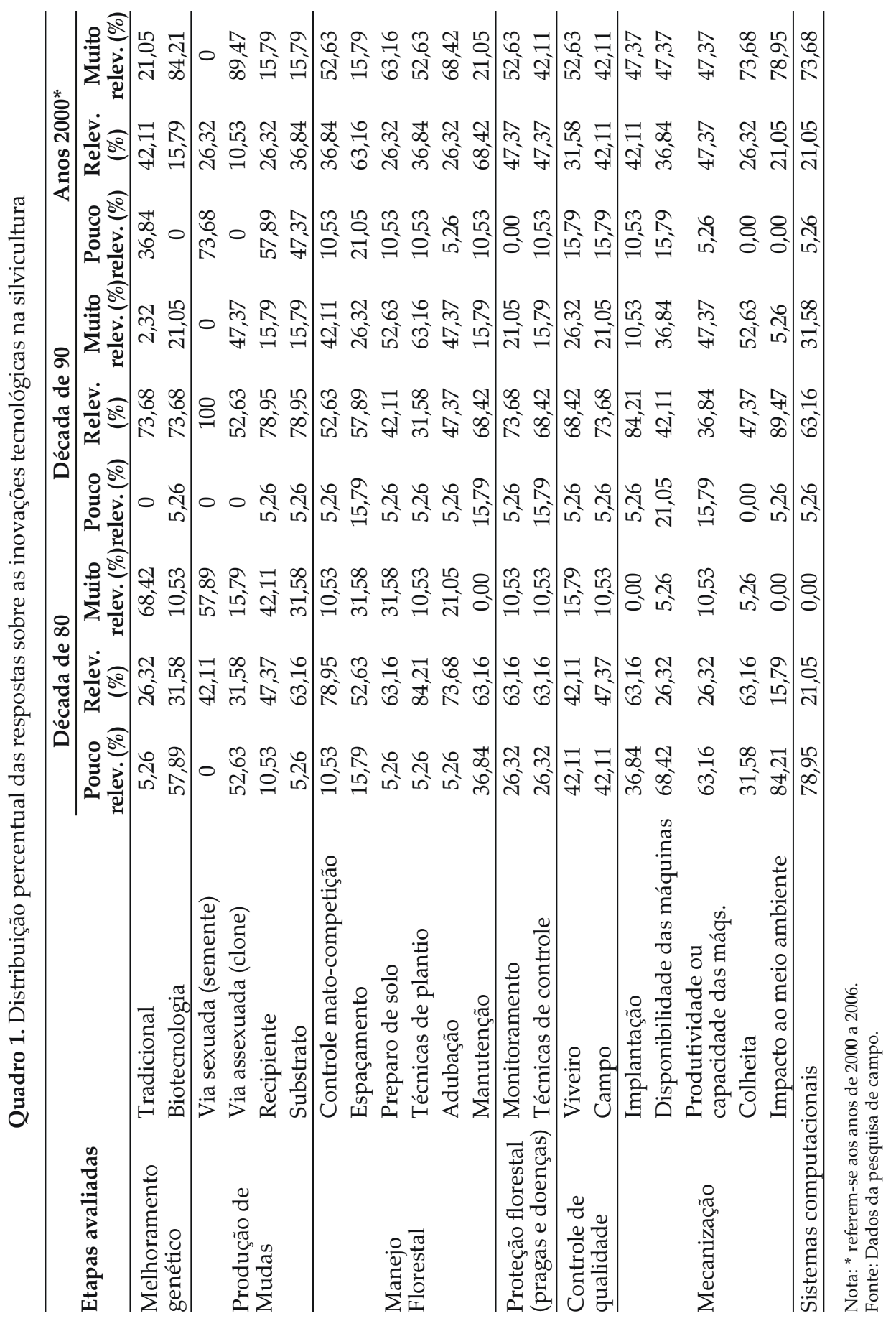

RESR, Piracicaba, SP, vol. 47, no 02, p. 485-517, abr/jun 2009 - Impressa em julho 2009 
Na década de 90, na área de melhoramento genético, a biotecnologia destacou-se como inovação tecnológica relevante, passando nos anos 2000 a ser classificada como muito relevante (segundo $84,21 \%$ dos entrevistados). Isso mostra a necessidade de se buscar processos que intensifiquem o crescimento das plantas, aumente a qualidade da madeira e traga maior resistência a doenças e pragas. Em relação à área de manejo florestal, os resultados mostraram que o controle mato-competição, espaçamento, adubação e manutenção foram considerados como inovações tecnológicas relevantes na década de 90.

Já nos primeiros seis anos dos anos 2000, as inovações tecnológicas referentes ao controle mato-competição e adubação foram classificados como muito relevantes. As inovações tecnológicas referentes ao preparo do solo e técnicas de plantio foram classificadas como muito relevante tanto na década de 1990 quanto nos seis primeiros anos dos anos 2000.

Em relação à produção de mudas, nos anos 90 e nos seis primeiros anos dos anos 2000, houve maior destaque para a produção via assexuada (por meio da clonagem). Esse tipo de produção passou a ser mais utilizada a fim de se obter ganhos genéticos de maneira mais rápida, além de maior uniformidade obtida nos plantios. De 1990 a 2006, de acordo com os resultados, intensificaram-se as linhas de pesquisa voltadas para o controle de qualidade nos viveiros florestais e no campo. Dos 19 questionários respondidos, $68,42 \%$ e 73,68\%, respectivamente, consideraram as inovações quanto ao controle de qualidade nos viveiros florestais e no campo, na década de 1990, como relevante. Nos anos 2000, essas inovações foram classificadas, conforme $52,63 \%$ e $42,11 \%$ dos entrevistados, como sendo muito relevantes.

As inovações sobre mecanização florestal ganharam impulso na década de 90. As etapas pesquisadas nessa área, classificadas como relevante nesse período, referem-se à implantação, disponibilidade de máquinas e impacto ao meio ambiente. Já as inovações quanto à produtividade das máquinas e na colheita foram consideradas como muito relevante nessa década. Contudo, foi a partir dos anos 2000 que os avanços tecnológicos nessa área se intensificaram. As inovações nas etapas da mecanização foram computadas como muito relevantes nos anos 2000. Os processos de mecanização das operações buscam a redução dos custos e o aumento de competitividade como forma de auferir ganhos em competitividade. Segundo Seixas (2005), a importância da colheita florestal no Brasil reflete-se na composição do custo da madeira, atingindo cerca de $25 \%$ de seu preço final. Dessa forma, faz-se necessária a redução desses custos como forma de aumentar a produtividade e reduzir os riscos de trabalho da mão-de-obra que trabalha nas florestas plantadas. Porém, deve-se acrescentar nesses avanços o problema da utilização das máquinas sobre o meio ambiente. De acordo com Seixas (2005), o tráfego de máquinas em uma floresta pode causar 
500 - Avaliação das pesquisas e inovações tecnológicas ocorridas na silvicultura e na produção industrial de celulose no Brasil

danos em árvores remanescentes, além de influenciar a qualidade dos recursos hídricos e gerar a compactação do solo florestal.

As inovações em relação aos sistemas computacionais não foram relevantes na década 80 . Já na década de 90, 63,16\% consideraram essa etapa como tendo inovações relevantes e nos anos 2000, 73,68\% dos entrevistados as classificaram como muito relevante. Esses avanços nos sistemas computacionais nos últimos anos são reflexos do aumento da demanda por dados confiáveis que agilizem e aperfeiçoem os fluxos de informação no setor florestal. Assim, o aprimoramento nessa área pode ser traduzido como a busca por maior eficiência e redução de custos das operações.

Visando quantificar ordinalmente as avaliações feitas sobre as inovações tecnológicas, atribuiu-se à variável classificada como pouco relevante a nota 1 , à classificação relevante a nota 2 e à classificação muito relevante a nota 3.

A Tabela 2 mostra a média da relevância atribuída a cada uma das inovações tecnológicas avaliadas nas décadas de 80 e 90 e nos anos 2000. A maioria das inovações tecnológicas ocorridas na silvicultura teve aumento em suas médias da década de 1980 para a década de 1990, da década de 1990 aos anos 2000 e da década de 1980 para os anos 2000, com exceção das inovações tecnológicas nas áreas de melhoramento genético tradicional, produção de mudas (via sexuada, recipiente e substrato) e manejo florestal referente à espaçamento. Da década de 1980 para a década de 1990, da década de 1990 para os anos 2000 e da década de 1980 para os anos 2000, as médias caem na área de melhoramento genético tradicional, produção de mudas (via sexuada e recipiente) e manejo florestal referente à espaçamento. Para a produção de mudas através de substrato, a média aumentou da década de 1980 para a de 1990, caiu da década de 1990 para os anos 2000 e comparando com a década de 1980 e os anos 2000 a média subiu. 
Tabela 2. Média do grau de relevância de cada inovação tecnológica na silvicultura nas décadas de 80 e 90 e nos anos 2000

\begin{tabular}{|c|c|c|c|c|}
\hline \multirow{2}{*}{ Etapas avaliadas } & & \multicolumn{3}{|c|}{ Médias } \\
\hline & & $\begin{array}{c}\text { Década } \\
\text { de } 80\end{array}$ & $\begin{array}{c}\text { Década } \\
\text { de } 90\end{array}$ & $\begin{array}{l}\text { Anos } \\
2000^{*}\end{array}$ \\
\hline \multirow{2}{*}{$\begin{array}{l}\text { Melhoramento } \\
\text { genético }\end{array}$} & Tradicional & 2,63 & 2,26 & 1,84 \\
\hline & Biotecnologia & 1,52 & 2,16 & 2,84 \\
\hline \multirow{4}{*}{ Produção de Mudas } & Via sexuada (semente) & 2,57 & 2,00 & 1,26 \\
\hline & Via assexuada (clone) & 1,63 & 2,47 & 2,89 \\
\hline & Recipiente & 2,31 & 2,10 & 1,57 \\
\hline & Substrato & 1,26 & 2,10 & 1,68 \\
\hline \multirow{6}{*}{ Manejo Florestal } & Controle mato-competição & 2,00 & 2,36 & 2,42 \\
\hline & Espaçamento & 2,16 & 2,10 & 1,94 \\
\hline & Preparo de solo & 2,26 & 2,47 & 2,52 \\
\hline & Técnicas de plantio & 2,26 & 2,47 & 2,52 \\
\hline & Adubação & 2,16 & 2,42 & 2,63 \\
\hline & Manutenção & 1,63 & 2,00 & 2,10 \\
\hline \multirow{2}{*}{$\begin{array}{l}\text { Proteção florestal } \\
\text { (pragas e doenças) }\end{array}$} & Monitoramento & 1,84 & 2,16 & 2,52 \\
\hline & Técnicas de controle & 1,84 & 2,00 & 2,31 \\
\hline \multirow{2}{*}{$\begin{array}{l}\text { Controle de } \\
\text { qualidade }\end{array}$} & Viveiro & 1,73 & 2,21 & 2,36 \\
\hline & Campo & 1,68 & 2,16 & 2,26 \\
\hline \multirow{5}{*}{ Mecanização } & Implantação & 1,63 & 2,05 & 2,36 \\
\hline & Disponibilidade das máquinas & 1,36 & 2,15 & 2,31 \\
\hline & $\begin{array}{l}\text { Produtividade ou } \\
\text { capacidade das máquinas }\end{array}$ & 1,47 & 2,31 & 2,42 \\
\hline & Colheita & 1,73 & 2,52 & 2,73 \\
\hline & Impacto ao meio ambiente & 1,15 & 2,00 & 2,79 \\
\hline \multicolumn{2}{|c|}{ Sistemas computacionais } & 1,21 & 2,26 & 2,68 \\
\hline
\end{tabular}

Nota: * referem-se aos anos de 2000 a 2006.

Fonte: Dados da pesquisa.

Com base na Tabela 3, que mostra os resultados do teste de Wilcoxon ${ }^{8}$, é possível verificar se as alterações ocorridas nas médias em cada uma das inovações tecnológicas, nos períodos analisados, são estatisticamente significativas com o nível de significância de 5\%. As alterações nas médias das inovações tecnológicas que foram significativas estão marcadas em negrito no valor $\mathrm{z}$ do teste de Wilcoxon.

$\overline{8}$ Como foi mencionado, o teste de Wilcoxon compara as variáveis duas a duas. Assim, por exemplo, é verificada a diferença entre cada etapa nas décadas de 80 versus 90 , década de 90 versus anos 2000 e década de 80 versus anos 2000. 
Avaliação das pesquisas e inovações tecnológicas ocorridas na silvicultura

e na produção industrial de celulose no Brasil

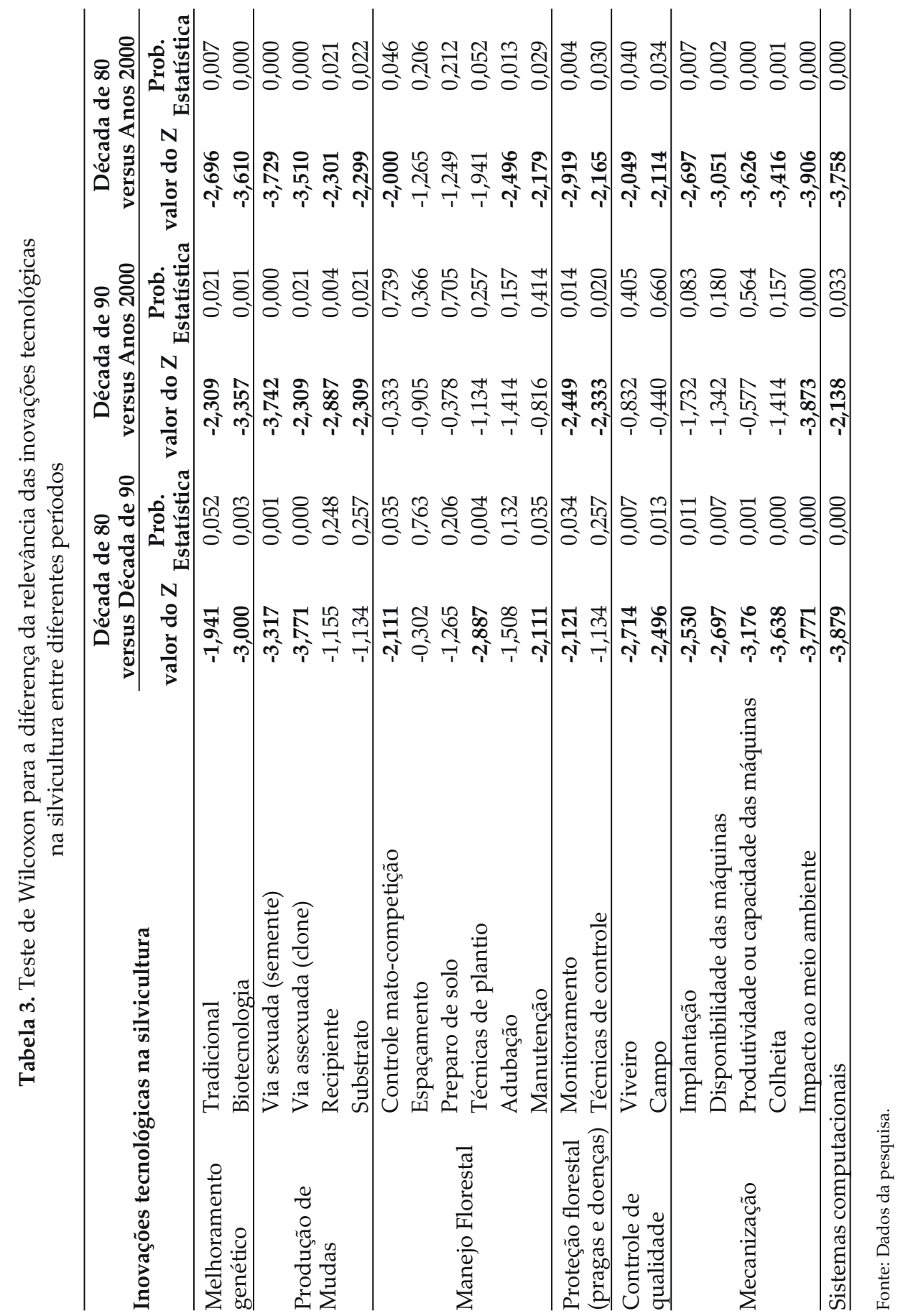

RESR, Piracicaba, SP, vol. 47, no 02, p. 485-517, abr/jun 2009 - Impressa em julho 2009 
Estatisticamente, é provado que o incremento de relevância das inovações tecnológicas, em todos os períodos analisados, ocorreu nos seguintes casos: melhoramento genético via biotecnologia, produção de mudas (vias sexuada e assexuada), monitoramento, impacto da mecanização sobre o meio ambiente e sistemas computacionais. As outras etapas do processo produtivo destacaram-se por crescimento da importância das inovações ocorridas da década de 80 para a de 90 ou da década de 90 para os anos 2000. Exceções são as pesquisas de espaçamento e preparo do solo, que não apresentaram significância estatística na alteração de relevância em termos de inovação tecnológica.

\subsection{Impactos das inovações tecnológicas sobre a produtividade da silvicultura}

Conforme Antonangelo e Bacha (1996), a relação entre pesquisa/inovação tecnológica e expansão da silvicultura e da indústria brasileira de celulose é estabelecida pela produtividade. Em geral, pode-se dizer que as inovações tecnológicas ocorridas na silvicultura brasileira provocaram aumento geral da produtividade que, por sua vez, reduziram os custos do reflorestamento/ florestamento, elevando a rentabilidade do setor, o qual leva a sua expansão.

Fruto das inovações tecnológicas comentadas no item 4.2, a produtividade da silvicultura cresceu fortemente, fazendo do Brasil o País de maior produtividade na produção de madeira para elaborar celulose e que consegue menor período de maturação da árvore para colheita. Segundo Bacha (2006, p. 21-23), "a produtividade média da eucaliptocultura em 1968 era de 17,5 st/ha/ano e passou em 2000 para $48 \mathrm{st} / \mathrm{ha} / \mathrm{ano}$. No caso da pinocultura, essas produtividades foram, respectivamente, 20 e $36 \mathrm{st} / \mathrm{ha} / \mathrm{ano}$. O ritmo de crescimento da produtividade da eucaliptocultura é maior do que o da pinocultura, ritmo de crescimento que diminui a partir de 1992. A taxa de crescimento geométrica anual da produtividade da eucaliptocultura entre 1968 e 2000 foi de $3,44 \%$ e da pinocultura foi de 2,12\%. No período de 1968 a 1991, a produtividade da eucaliptocultura cresceu à taxa de $4,42 \%$ a.a. e da pinocultura à taxa de $2,39 \%$ a.a.. No período de 1991 a 2000, essas taxas foram, respectivamente, $0,86 \%$ a.a. e $0,7 \%$ a.a." (...) "Observa-se que as árvores crescem mais rápido e se maturam mais cedo no Brasil. Em nosso país, é possível colher uma árvore para produzir celulose aos 7 anos, enquanto na Suécia e na Finlândia esse tempo é, no mínimo, de 35 anos. Outros países, tais como Indonésia e Austrália, também conseguem colher árvores para produção de celulose após 7 anos de seu plantio, mas com produtividade $50 \%$ menor do que a brasileira, ou seja, conseguem incremento médio anual de 20 a 25 st/ha/ano frente aos 45 a 50 st/ha/ano do Brasil."

Conforme a Tabela 4, a qual compara a produtividade da silvicultura brasileira $\left(\mathrm{m}^{3} / \mathrm{ha} / \mathrm{ano}\right)$ com a de outros países, verifica-se que a produtividade brasileira é maior em relação a todos os outros países concorrentes. Sendo assim, 
o contínuo melhoramento dos procedimentos da silvicultura e da indústria possibilitou ao Brasil alcançar posição altamente competitiva frente a seus principais competidores no mercado internacional.

Tabela 4. Produtividade média da silvicultura em alguns países segundo as espécies florestais $\left(\mathrm{m}^{3} / \mathrm{ha} / \mathrm{ano}\right)$

\begin{tabular}{lcc}
\hline Países & Coníferas & Folhosas \\
\hline Brasil & 25 & 30 \\
Chile & 22 & n.d. \\
Nova Zelândia & 22 & n.d. \\
África do Sul & 18 & n.d. \\
Estados Unidos & 10 & 15 \\
Suécia & 4 & n.d. \\
Canadá & 2 & 5 \\
Portugal & n.d. & 12
\end{tabular}

Nota: n.d. = informação não disponível

Fonte: Garlipp (2005b).

Essa grande produtividade dos plantios florestais faz a madeira ter pouca importância no custo de produzir uma tonelada de celulose no Brasil. As despesas com madeira totalizaram, em 2005, US\$ 100 por tonelada produzida de celulose no Brasil. Esse valor para Espanha, Portugal, Finlândia, Suécia e Canadá foram, respectivamente, US\$227,90, US\$ 209,90, US\$ 188,86, US\$224,64 e US\$ 138,81 (de acordo com dados fornecidos pela RISI Inc.).

\section{Pesquisa e inovações tecnológicas na etapa industrial de produção de celulose no Brasil}

\subsection{Evolução das pesquisas e inovações tecnológicas na produção industrial de celulose no Brasil}

Segundo Higashi (1993), as pesquisas geradas no Brasil na área florestal são bem mais amplas que as geradas na área industrial, já que as empresas aqui instaladas foram fortemente condicionadas a adotar uma estratégia tecnológica ofensiva na área florestal, procurando obter alta produtividade aliada à uniformidade das florestas. Por outro lado, na área industrial a estratégia foi defensiva, uma vez que as firmas líderes possuem somente capacidade de operação e adaptação das tecnologias industriais, gerando, dessa forma, 
processos de inovação incremental. Dessa maneira, é na área florestal que o país mais se destacou em termos de desenvolvimento tecnológico.

De acordo com Valença (2001), o parque fabril de bens de capital instalado no Brasil, que atende ao setor de celulose e papel, utiliza tecnologia gerada pelas matrizes estrangeiras das empresas aqui instaladas. Sendo assim, os atuais produtores de bens de capital para as indústrias de celulose e papel instaladas no Brasil são controlados por empresas multinacionais, e delas dependentes em relação à tecnologia. Ainda segundo o autor, essa situação proporcionou melhoria na qualidade técnica dos equipamentos. Entretanto, tal situação dificultou a disponibilidade de mão-de-obra técnica local e a prestação de serviços pelas empresas usuárias de bens de capital na indústria de celulose e papel. Além disso, as maiores empresas nacionais especializadas em montagem praticamente desapareceram do mercado, o mesmo acontecendo com empresas de engenharia.

Em relação à conduta das empresas produtoras de celulose frente ao mercado internacional, observa-se que elas têm como principais estratégias, de acordo com Hilgemberg e Bacha (2003), a produção de bens que atendam às exigências mundiais.

Com a descoberta, em meados da década de 1980, das dioxinas e furanos nos efluentes das polpas, oriundos do branqueamento da celulose com cloro, o setor de celulose e papel passou a sofrer forte pressão para alterar o processo de branqueamento. Assim, observou-se, no início da década de 90, maior concentração das pesquisas nas áreas de processos de polpação e branqueamento. Esses trabalhos foram totalmente direcionados para a madeira de eucalipto, uma vez que os conhecimentos disponíveis relacionados à polpação e branqueamento desta matéria-prima são escassos na literatura mundial. Tiveram destaque os trabalhos que buscaram o aumento do rendimento de processos de polpação e a eliminação de compostos clorados nas seqüências de branqueamento.

Segundo Hilgemberg e Bacha (2003), duas alternativas surgiram para alterar o processo de branqueamento: a substituição do cloro elementar pelo dióxido de cloro no branqueamento da celulose, gerando o processo Elementar Chlorine Free (ECF), ou o branqueamento com peróxido de hidrogênio, originando o processo Totally Chlorine Free (TCF). No entanto, pelo fato da celulose TCF ter maior custo de produção do que a celulose ECF e aquela não ser livre de críticas quanto aos danos ambientais e nem ter diferencial de preço em relação à celulose ECF, as empresas de celulose de todo o mundo passaram a dar preferência à produção de ECF. Em 2002, a produção à base de dióxido de cloro (processo ECF) para o branqueamento da celulose alcançou 64 milhões de toneladas. Espera-se que tal produção continue a crescer devido à entrada de novos produtores, utilizando o processo ECF no Brasil, Chile, Alemanha e China (TRENDS IN WORDS..., 2002). 
506 - Avaliação das pesquisas e inovações tecnológicas ocorridas na silvicultura e na produção industrial de celulose no Brasil

As empresas brasileiras, com a finalidade de inserir definitivamente o setor brasileiro de celulose e papel nos padrões mundiais passaram, a partir da segunda metade da década de 1980, a adotar uma conduta pró-ativa frente às pressões ambientais. Segundo Saraiva et al. (2003), as empresas brasileiras passaram a optar pelo processo com dióxido de cloro (ECF), alcançando redução de $60 \%$ na emissão de DBO (descarga emitida pela celulose standard baseada em cloro elementar) na linha de branqueamento. Além disso, com esse novo processo foi possível utilizar menor volume de água consumida por tonelada de celulose. Trabalhando nessa nova linha, a Ripasa, por exemplo, reduziu seu consumo de cerca de $35 \mathrm{~m}^{3} / \mathrm{t}$ da antiga linha para $12 \mathrm{~m}^{3}$ de água/t de celulose usando o sistema ECF.

Além dessas preocupações com as questões ambientais, o cenário mundial tem mostrado que o desenvolvimento tecnológico na produção de celulose e papel está sendo realizado por meio de uma parceria entre o setor privado e o setor público, através dos relacionamentos entre empresas, universidades e centros de pesquisa (como mostrado no início da seção 3).

Outro ponto enfrentado pelo segmento industrial brasileiro refere-se à reciclagem de papel no País. Conforme Foelkel (2001), apesar de o lixo urbano no Brasil não ser muito rico em papel, uma vez que o consumo per capita de papel não é alto (cerca de $40 \mathrm{~kg} /$ habitante/ano), a nossa sociedade vive em grandes cidades, o que favorece o acúmulo, coleta e seleção de papéis usados e de aparas geradas em fase de pós-consumo. Dessa maneira, o papel é reciclado no País, de acordo com a Tabela 5, a uma taxa de $46 \%$, mostrando que essa atividade tem excelente performance, levando em conta a pobre qualidade do lixo. Essa taxa classifica o País em oitavo lugar no ranking mundial da taxa de recuperação de papéis recicláveis. Os principais usos destinados ao papel reciclado são para a fabricação de embalagens de papelão ondulado, papéis higiênicos, produtos de polpa moldada e papéis, além de cartões para embalagens.

A reciclagem de papel no País, segundo Foelkel (2001), compete por market-share com o mercado de fibra virgem, gerando reações conflituosas. Todavia, deve-se considerar que essa atividade de reciclagem, além de ser ecologicamente correta e economicamente viável, tem propiciado a geração de excedentes de polpa para exportação, gerando empregos, divisas e contribuindo com a melhoria da balança comercial brasileira. 
Tabela 5. Taxa de recuperação de papéis recicláveis em 2005 nos principais países

\begin{tabular}{ccc}
\hline Posição & Países & $\begin{array}{c}\text { Taxa de recuperação de } \\
\text { papéis recicláveis (\%) }\end{array}$ \\
\hline 1 & Coréia do Sul & 86,30 \\
2 & Japão & 68,40 \\
3 & Alemanha & 68,00 \\
4 & Espanha & 54,00 \\
5 & Reino Unido & 51,90 \\
6 & Itália & 49,20 \\
7 & Estados Unidos & 47,50 \\
8 & Brasil & 46,00 \\
9 & Argentina & 44,70 \\
10 & México & 41,90 \\
11 & Malásia & 38,70 \\
12 & Polônia & 33,20 \\
13 & China & 30,40 \\
\hline
\end{tabular}

Fonte: Bracelpa (2006)

\subsection{Importância das inovações tecnológicas na produção industrial de celulose: de 1980 a 2006}

Na área industrial, foram respondidos 15 questionários e as respostas estão no Quadro 2. Na década de 80, as inovações tecnológicas relevantes concentraram-se na qualidade da polpa, produção de papel, desenvolvimento de produtos, branqueamento, qualidade da madeira, polpação e matriz energética.

$\mathrm{Na}$ década de 90, as inovações tecnológicas classificadas como relevantes referem-se à qualidade da madeira (segundo 73,33\% dos entrevistados), preparação da madeira (73,33\%), polpação (53,33\%), qualidade da polpa celulósica (80\%), matriz energética $(66,67 \%)$, desenvolvimento de produtos (53,33\%), controle da poluição do ar (46,67\%), produção de papel (66,67\%), genômica e OGMS $(66,67 \%)$ e formação de recursos humanos $(86,67 \%)$. Já as inovações referentes à branqueamento, tratamento de efluentes e máquinas e equipamentos foram classificadas como de maior impacto na área industrial, recebendo a maior porcentagem como sendo muito relevantes.

De 2000 a 2006, de modo geral, houve avanços tecnológicos em praticamente todas as áreas de pesquisa industrial. Os itens qualidade da madeira, polpação, branqueamento, tratamento de efluentes, matriz energética, controle da poluição do ar, desenvolvimento de produtos, máquinas e equipamentos, biotecnologia industrial, genômica e OGMS, e formação de recursos humanos foram classificados como muito relevantes pela maior parte dos entrevistados.

A Tabela 6 mostra a média da relevância atribuída a cada uma das inovações tecnológicas ocorridas no processo industrial da celulose no Brasil nas décadas de 80 e 90 e nos anos 2000. 
508 - Avaliação das pesquisas e inovações tecnológicas ocorridas na silvicultura e na produção industrial de celulose no Brasil

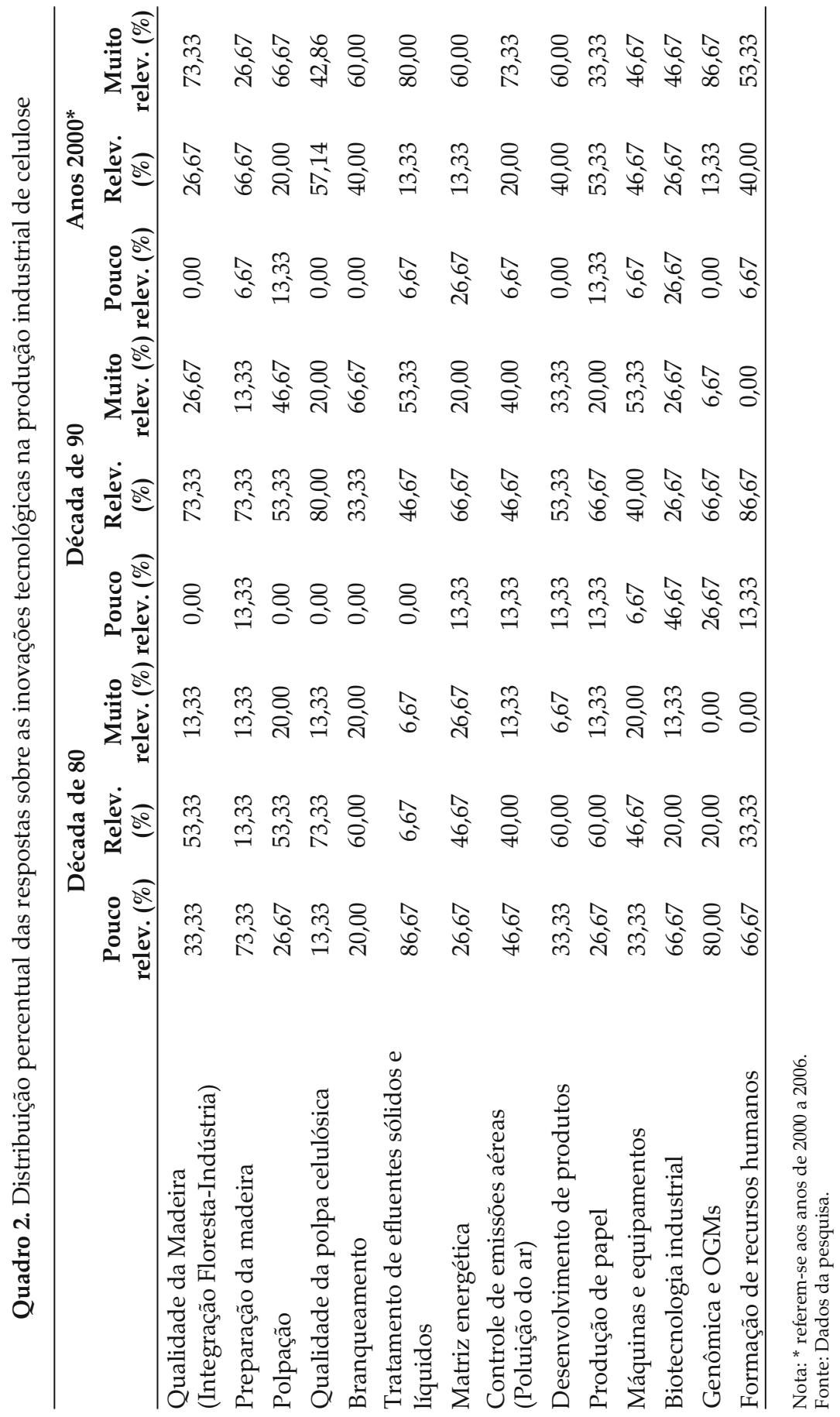

RESR, Piracicaba, SP, vol. 47, no 02, p. 485-517, abr/jun 2009 - Impressa em julho 2009 
Tabela 6. Média do grau de relevância de cada inovação tecnológica na área industrial de produção de celulose no Brasil nas décadas de 80 e 90 e nos anos 2000

\begin{tabular}{lccc}
\hline \multirow{2}{*}{ Etapas avaliadas } & \multicolumn{3}{c}{ Médias } \\
\cline { 2 - 4 } Qualidade da Madeira & 1,80 & 2,26 & 2,73 \\
(Integração Floresta-Indústria) & 1,40 & 2,00 & 2,20 \\
Preparação da madeira & 1,93 & 2,46 & 2,53 \\
Polpação & 2,00 & 2,20 & 2,43 \\
Qualidade da polpa celulósica & 2,00 & 2,66 & 2,66 \\
Branqueamento & 1,20 & 2,53 & 2,73 \\
Tratamento de efluentes sólidos e líquidos & 2,00 & 2,06 & 2,33 \\
Matriz energética & 1,66 & 2,26 & 2,66 \\
Controle de emissões aéreas (Poluição do ar) & 1,73 & 2,20 & 2,60 \\
Desenvolvimento de produtos & 1,86 & 2,06 & 2,20 \\
Produção de papel & 1,86 & 2,46 & 2,40 \\
Máquinas e equipamentos & 1,46 & 1,80 & 2,20 \\
Biotecnologia industrial & 1,20 & 1,80 & 2,86 \\
Genômica e OGMs & 1,33 & 1,86 & 2,46 \\
Formação de recursos humanos
\end{tabular}

Fonte: Dados da pesquisa. Nota: * referem-se aos anos de 2000 a 2006.

As médias da relevância das inovações tecnológicas em todas as etapas analisadas na Tabela 6 foram crescentes da década de 1980 para a de 1990 e da década de 1990 para os anos 2000, com exceção das máquinas e equipamentos em que a média teve elevação da década de 80 para a de 90 e queda da década de 90 aos anos 2000; e do branqueamento, cuja média sobe da década de 80 para a de 90 e permanece estável nos anos 2000. Comparando com a década de 1980 e os anos 2000 , nota-se que as relevâncias das inovações tecnológicas ampliaram em todas as atividades ressaltadas na Tabela 6.

Com base na Tabela 7, verifica-se que da década de 1980 para a de 1990 o aumento das médias foi estatisticamente significativo, com o nível de significância de 5\%, para as seguintes inovações tecnológicas: qualidade da madeira, preparação da madeira, polpação, branqueamento, tratamento de efluentes, controle de emissões aéreas, desenvolvimento de produtos, máquinas e equipamentos, genômica e OGMS e formação de recursos humanos. Da década de 1990 aos anos 2000, os aumentos tiveram significância estatística para as inovações tecnológicas referentes à qualidade da madeira, preparação da madeira, genômica e OGMS e formação de recursos humanos. Da década de 1980 para os anos 2000, praticamente todos os aumentos foram significativos, com exceção de matriz energética e produção de papel. 
Avaliação das pesquisas e inovações tecnológicas ocorridas na silvicultura e na produção industrial de celulose no Brasil

Tabela 7. Teste de Wilcoxon para a diferença das inovações tecnológicas na produção industrial de celulose entre diferentes períodos

\begin{tabular}{|c|c|c|c|c|c|c|}
\hline \multirow{2}{*}{$\begin{array}{l}\text { Inovações tecnológicas } \\
\text { na indústria }\end{array}$} & \multicolumn{2}{|c|}{$\begin{array}{c}\text { Década de } 80 \\
\text { versus Década de } 90 \\
\end{array}$} & \multicolumn{2}{|c|}{$\begin{array}{c}\text { Década de } 90 \\
\text { versus Anos } 2000\end{array}$} & \multicolumn{2}{|c|}{$\begin{array}{c}\text { Década de } 80 \\
\text { versus Anos } 2000\end{array}$} \\
\hline & valor $\mathrm{Z}$ & $\begin{array}{c}\text { Prob. } \\
\text { estatística }\end{array}$ & valor $\mathrm{Z}$ & $\begin{array}{c}\text { Prob. } \\
\text { estatística }\end{array}$ & valor $\mathrm{Z}$ & $\begin{array}{c}\text { Prob. } \\
\text { estatística }\end{array}$ \\
\hline Qualidade da madeira & $-2,333$ & 0,02 & $-2,646$ & 0,008 & $-2,81$ & 0,005 \\
\hline Preparação da madeira & 3,000 & 0,003 & $-1,342$ & 0,18 & $-2,972$ & 0,003 \\
\hline Polpação & $-2,530$ & 0,011 & $-0,447$ & 0,655 & $-2,324$ & 0,020 \\
\hline $\begin{array}{l}\text { Qualidade da polpa } \\
\text { celulósica }\end{array}$ & $-1,732$ & 0,083 & $-1,667$ & 0,096 & $-2,530$ & 0,011 \\
\hline Branqueamento & $-3,162$ & 0,002 & $-0,333$ & 0,739 & $-2,165$ & 0,030 \\
\hline Tratamento de efluentes & $-3,272$ & 0,001 & $-1,134$ & 0,257 & $-3,361$ & 0,001 \\
\hline Matriz energética & $-0,302$ & 0,763 & $-1,265$ & 0,206 & $-0,686$ & 0,493 \\
\hline $\begin{array}{l}\text { Controle de emissões } \\
\text { aéreas }\end{array}$ & $-2,324$ & 0,02 & $-1,897$ & 0,058 & $-2,517$ & 0,012 \\
\hline $\begin{array}{l}\text { Desenvolvimento de } \\
\text { produtos }\end{array}$ & $-2,646$ & 0,008 & $-1,897$ & 0,058 & $-3,127$ & 0,002 \\
\hline Produção de papel & $-1,732$ & 0,083 & $-1,000$ & 0,317 & $-1,633$ & 0,102 \\
\hline Máquinas e equipamentos & $-2,460$ & 0,014 & $-0,577$ & 0,564 & $-1,994$ & 0,046 \\
\hline Biotecnologia industrial & $-1,318$ & 0,187 & $-1,73$ & 0,084 & $-2,041$ & 0,041 \\
\hline Genômica e OGMS & $-3,000$ & 0,003 & $-3,557$ & 0,000 & $-3,542$ & 0,000 \\
\hline $\begin{array}{l}\text { Formação de recursos } \\
\text { humanos }\end{array}$ & $-2,828$ & 0,005 & $-3,000$ & 0,003 & $-3,153$ & 0,002 \\
\hline
\end{tabular}

Fonte: Dados da pesquisa.

\subsection{Impactos das inovações tecnológicas na evolução da indústria de celulose no Brasil}

Considerando os dados da Bracelpa, em 1989, o Brasil exportou 1.022.877 toneladas de celulose, passando, em 2005, para 4.988.790 toneladas desse produto. Houve, portanto, crescimento de $387,72 \%$ das exportações nesses 15 anos. Ao mesmo tempo, o Brasil produziu, em 1989, 4.423.000 toneladas de celulose passando, em 2005, para 10.352.113 toneladas. Houve, dessa forma, o crescimento de $134,05 \%$, nesse período, na produção de celulose. Isto mostra um direcionamento para as exportações da indústria brasileira de celulose. Em 1989, as exportações representaram 23,1\% da produção brasileira de celulose e em 2005 essa percentagem foi de $48,19 \%$.

Esse crescimento das exportações está relacionado ao aumento da competitividade brasileira na produção de celulose. Essa é totalmente elaborada a partir de madeira oriunda de florestas plantadas (o que atende às pressões 
ambientais) e está sendo produzida a custos decrescentes (conforme gráfico 1), fruto das pesquisas e inovações tecnológicas no setor de celulose e papel. Dessa forma, o Brasil vem conquistando posição de destaque no comércio internacional de celulose, ocupando a 7a posição na produção mundial desse produto, incluindo todos os tipos de celulose de mercado, e a 1a posição na produção de celulose de fibra curta de eucalipto.

Os fatores que mais contribuíram para o aspecto declinante do custo de produção associam-se à redução com custos dos insumos: energia, trabalho e produtos químicos.

Gráfico 1. Evolução do custo da energia, dos produtos químicos e do trabalho na produção de uma tonelada de celulose branqueada de fibra curta para o Brasil em US\$/ton.

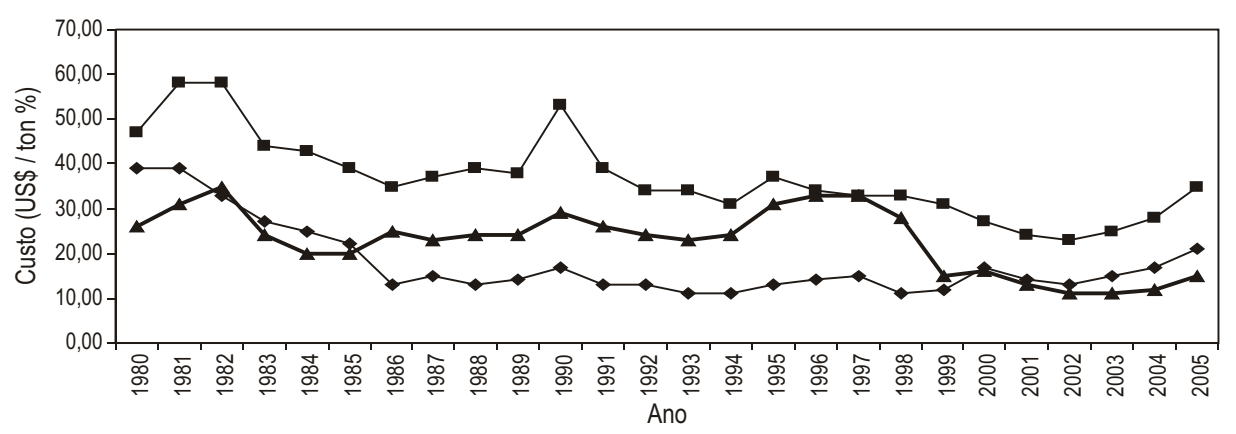

$$
\longrightarrow \text { energia } \longrightarrow \text { produtos químicos } \longrightarrow \text { trabalho }
$$

Fonte: RISI (2006)

De acordo com o gráfico 1, esses custos, em dólares correntes, apresentam tendência de queda ao longo do período analisado. Em 1980, os custos da energia, dos produtos químicos e do trabalho foram, respectivamente, US\$39, US\$ 47 e US\$ 26 por tonelada produzida de celulose no Brasil e, em 2005, esses custos foram, respectivamente, US\$21, US\$ 35 e US\$15. Em 1980, os custos da energia, dos produtos químicos e do trabalho representaram 13\%, 15,5\% e 8,61\%, respectivamente, do custo variável de produção de uma tonelada de celulose de fibra curta no Brasil. Por outro lado, em 2005, esses custos participaram com 7\%, $12 \%$ e $5 \%$, respectivamente, no custo variável de produção de uma tonelada de celulose no País.

Com o esforço consistente na atualização tecnológica das operações de produção de celulose, o segmento industrial desse produto vem apresentando melhorias nos indicadores de eficiência nessas operações. O gráfico 2 evidencia que houve aumento da eficácia na indústria brasileira de celulose por meio dos indicadores técnicos de consumo de madeira na produção de celulose. $\mathrm{O}$ 
512 - Avaliação das pesquisas e inovações tecnológicas ocorridas na silvicultura e na produção industrial de celulose no Brasil

consumo anual de madeira para produzir uma tonelada de celulose apresentou tendência de queda no período de 1992 a 2007, sendo que, nesse período, houve redução de 13,62\% na quantidade de madeira para produzir uma tonelada de celulose. Isso está associado às inovações tecnológicas ocorridas na silvicultura, as quais permitiram trocar sementes por clones selecionados; e as melhorias na parte industrial. Além disso, o consumo de água na produção de cada tonelada de celulose reduziu-se em $42 \%$ no período de 1992 a 2007, o que evidencia uma melhor gestão dos efluentes líquidos nas fábricas de celulose, ou seja, o reaproveitamento de efluentes dentro da própria fábrica, permitindo a reutilização da água e a diminuição cada vez mais acentuada de seu consumo.

Segundo o estudo realizado pela Empresa de Pesquisa Energética (EPE), em 2005 , em relação ao consumo de energia, o setor de celulose e papel tem utilizado um consumo específico médio de energia elétrica de $1.000 \mathrm{kWh} / \mathrm{t}$, tanto para a celulose quanto para o papel. No entanto, convém ressaltar que este segmento industrial, pelas características específicas do seu processo de produção, gera diversos produtos residuais, tais como o licor negro, lixívia, cuja queima é apropriada para a co-geração de energia. Atualmente, a parcela de co-geração no setor já é elevada e estima-se que quase toda a expansão futura da capacidade instalada do setor de papel e celulose seja atendida via co-geração de energia elétrica.

Gráfico 2. Evolução do consumo de madeira (volume em $\mathrm{m} 3$ por tonelada de celulose $\mathrm{m} 3 /$ tcel) e do consumo de água (metros cúbicos de água por tonelada de celulose seca ao ar - $\mathrm{m} 3 \mathrm{H} 2 \mathrm{O} / \mathrm{tsa}$ ) na produção de uma tonelada de celulose

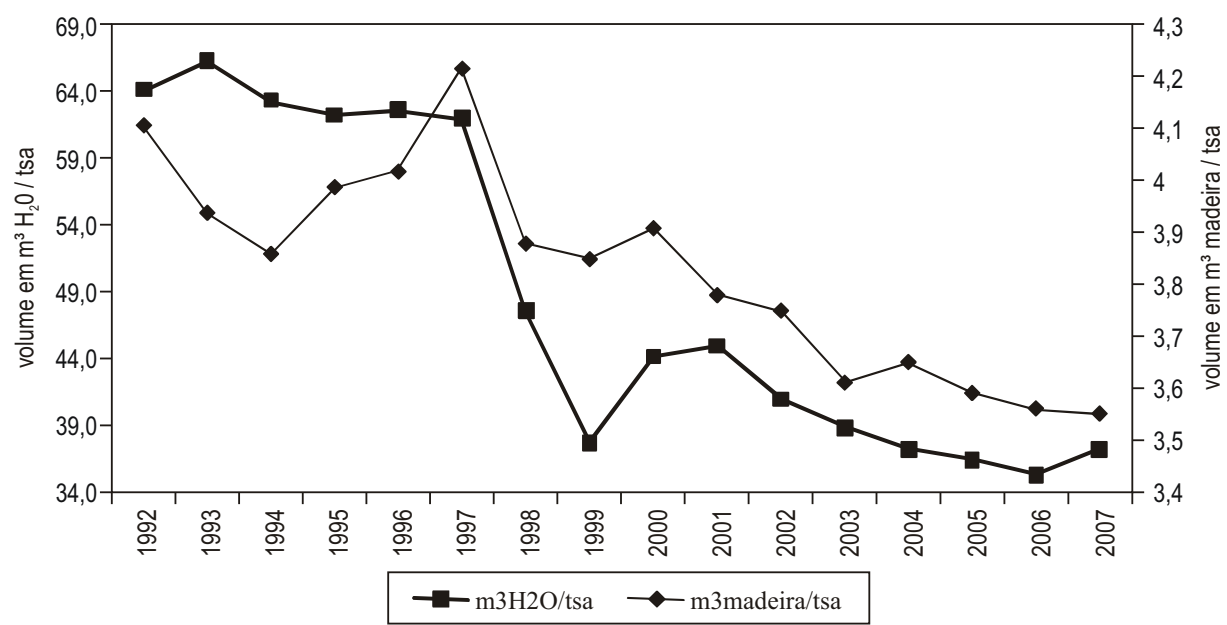

Fonte: Relatórios Anuais Aracruz 


\section{Considerações finais}

O objetivo geral desse trabalho foi analisar a evolução das pesquisas e inovações tecnológicas ocorridas na silvicultura e na produção industrial de celulose no Brasil, dando ênfase aos impactos dessas atividades para a expansão da indústria de celulose no Brasil. $\mathrm{O}$ trabalho distingue pesquisa e inovação tecnológica. A primeira gera um conhecimento que, ao ser adotado, gera um novo produto, processo ou melhoria deles (que são as inovações de produto ou processo).

O presente trabalho combinou diferentes metodologias e dados para alcançar o objetivo supracitado e considerando a diferença entre pesquisa e inovação tecnológica. Inicialmente, adotou-se a análise interpretativa de dados secundários para identificar as principais pesquisas, florestal e industrial, geradas nas décadas de 80 e 90 e nos anos 2000. Em seguida, usando uma amostra intencional de estudiosos e gerentes de empresas, avaliou-se a relevância dessas pesquisas em se tornar inovação tecnológica. Complementando esta última análise, um teste estatístico não paramétrico foi utilizado (o teste de Wilcoxon) para identificar que tipos de inovação têm aumentado sua relevância.

Foi demonstrado nesse estudo que o Brasil realizou grandes inovações tecnológicas em sua silvicultura, as quais se baseiam em pesquisas realizadas no País. Ocorreram grandes saltos na área de melhoramento genético e na área de adubação, o que contribuiu para melhorar os níveis de fertilidade do solo. Estas pesquisas surgiram das pressões de grupos de interesses sobre órgãos de pesquisas (em especial as universidades públicas), gerando resultados efetivos em relação a uma matriz ex-ante de retornos esperados, como proposto no modelo de De Janvry (1978). As despesas com madeira na composição do custo de produção de uma tonelada de celulose fizeram do Brasil um dos países mais competitivos na produção de celulose.

Além das inovações na silvicultura, foram abordadas as pesquisas e inovações tecnológicas ocorridas na produção industrial de celulose. A fim de atender às exigências mundiais em relação aos padrões ambientais, as empresas de celulose e papel passaram a substituir o cloro elementar no processo de branqueamento pelo dióxido de cloro, gerando o processo ECF (Elementar Chlorine Free), o qual reduziu as emissóes de poluentes nessa atividade. As inovações na área industrial são basicamente de processo, adaptando a tecnologia desenvolvida no exterior.

As atividades de pesquisa florestal e industrial no Brasil evidenciam uma forte integração entre empresas, universidades e governo, gerando novos produtos e processos que aumentaram a produtividade da indústria de celulose. Isto diminuiu o custo do produto gerado no País e permitiu a expansão da produção e exportação de celulose. 
O grande desafio para a indústria de celulose no Brasil é continuar a gerar novas pesquisas e inovações de modo a manter ou ampliar sua competitividade. Os resultados do teste de Wilcoxon para o período mais recente sugerem que esses esforços serão mais promissores na área florestal do que na industrial, pois essa última depende de tecnologia gerada fora do País e a pesquisa florestal tem um forte dinamismo nacional. De acordo com estudos recentes, nota-se que as empresas de celulose e papel no Brasil, com a finalidade de manter competitividade no mercado mundial, continuam buscando novas pesquisas e tecnologias que visem a aumentar a produtividade do eucalipto, como, por exemplo, encurtar o tempo de crescimento dessa espécie no Brasil como forma de obter ganhos em produtividade em relação aos concorrentes. Outro desafio da indústria de celulose no Brasil é buscar novas aplicações às matérias-primas que são desperdiçadas ao longo do processo produtivo. No caso da lignina ${ }^{9}$ (que gera o chamado "licor negro"), esta vem sendo queimada nas caldeiras das fábricas do setor para a co-geração de energia, uso que é considerado menos nobre, uma vez que este material pode ser reaproveitado como fonte renovável de segunda geração na produção do etanol celulósico. Nos Estados Unidos já são feitos vultosos investimentos em pesquisas de produção de etanol a partir de fontes renováveis. Além da produção do etanol celulósico, estudos apontam que o "licor negro" também pode ser matéria-prima para a produção de fibra carbono. Neste cenário, a continuidade da parceria entre entidades de pesquisas, empresas e governo é o principal caminho para que a indústria de celulose se mantenha competitiva no cenário internacional.

\section{Referências Bibliográficas}

ANTONANGELO, A. As inovações tecnológicas na silvicultura brasileira e seus impactos sobre a expansão desta atividade. 1996. 156 p. Dissertação (Mestrado em Economia Aplicada) - Escola Superior de Agricultura "Luiz de Queiroz", Universidade de São Paulo, Piracicaba, 1996.

ANTONANGELO, A.; BACHA, C.J.C. As fases da silvicultura no Brasil. Revista Brasileira de Economia, Rio de Janeiro, v. 52, n. 1, p. 207-209, 1998a.

\footnotetext{
${ }^{9}$ A lignina é uma substância encontrada nas plantas terrestres, cuja função é conferir rigidez, impermeabilidade e resistência aos tecidos vegetais. Um dos principais objetivos da fabricação de papel é reduzir o conteúdo de lignina na madeira que une as fibras de celulose, a fim de produzir a massa de papel. Para tanto, processos químicos são utilizados como forma de aumentar a solubilidade dessa substância, produzindo licores escuros que podem servir de fonte para outros produtos químicos ou combustível para as caldeiras das fábricas de celulose e papel.
} 
ANTONANGELO, A.; BACHA, C.J.C. As inovações tecnológicas na silvicultura brasileira e seus impactos sobre a produtividade desta atividade. In: AGUIAR, D.R.D.; PINHO, J.B. O agronegócio brasileiro: desafios e perspectivas. Brasília: SOBER, 1998b. v. 2, p. 333-348.

ARACRUZ. Relatório anual de sustentabilidade. São Paulo, 1992-2007. Disponível em: http://www.aracruz.com.br. Acesso em: 20 ago.

ASSOCIAÇÃO BRASILEIRA DE CELULOSE E PAPEL - BRACELPA. Relatório estatístico da BRACELPA. São Paulo, 1981-2006.

ASSOCIAÇÃO BRASILEIRA DA INDÚSTRIA DE MADEIRA PROCESSADA MECANICAMENTE - ABIMCI. Estudo setorial 2004. 52 p. Disponível em: $<$ http://www.abimci.com.br/port/03Dados/0308EstSet2005/ 0306Quadro.html>. Acesso em: 20 mar. 2006.

BACHA, C.J.C. Estudo prospectivo sobre silvicultura, manejo florestal, madeira e celulose. Relatório de pesquisa. Piracicaba: ESALQ, Depto. Economia, Administração e Sociologia, nov. 2006. 106 p. Relatório técnico.

BARRICHELLO, L.E.G. Universidade-empresa, integração beneficia o setor. Visão Agrícola, Piracicaba, v. 2, n. 4, p. 101-102, jul./dez. 2005.

BRASIL. Ministério da Ciência e Tecnologia. Sistema de análise de informações de comércio exterior. Disponível em: < http://www.aliceweb.desenvolvimento.gov.br $>$. Acesso em: 19 ago. 2006.

BRASIL. Ministério da Ciência e Tecnologia. Ciência e tecnologia no setor florestal brasileiro: diagnóstico, prioridades e modelo de financiamento: síntese. Piracicaba, jun. 2002. 176 p.

CAMPOS, H.D. Estatística experimental não-paramétrica. 3. ed. Piracicaba: ESALQ, Depto. Matemática e Estatítica, 1979. v. 2.

CRUZ, E.S. Análise do comércio mundial de celulose e papel. 2001. 145 p. Dissertação (Mestrado em Engenharia Florestal) - Universidade Federal de Lavras, Lavras, 2001.

CRUZ, H.N. Observações sobre a mudança tecnológica em Schumpeter. Estudos Econômicos, v. 18, n. 3, p. 433-448, set./dez. 1988.

DE JANVRY, A. Social structure and biased technical change in Argentine agriculture. In BINSWANGER, H.P.; RUTTAN, V.W. Induced innovation; technology, institutions and development. Baltimore: Johns Hopkins University Press, 1978, p. 297-323. 
516 - Avaliação das pesquisas e inovações tecnológicas ocorridas na silvicultura e na produção industrial de celulose no Brasil

EMPRESA DE PESQUISA ENERGÉTICA. Consumo e energia. Disponível em: $<$ http://www.epe.gov.br/mercado/Premissas/Cap\%202\%20Consumo\%20Industrial.pdf $>$. Acesso em: 11 out. 2006.

FOELKEL, C. Competitividade, inovação \& cooperação no setor. O Papel, São Paulo, v. 72, n. 8, p. 27-29, dez. 2003.

FOELKEL, C. Fibras virgens e/ou fibras recicladas? O Papel, São Paulo, v. 67, n. 3, p. 32-33, set. 2001 .

GARLIPP, R. Certificação permite avaliar e monitorar operações florestais. Visão Agrícola, Piracicaba, v. 2, n. 4, p. 88-91, jul./dez. 2005a.

GARLIPP, R. Eficiência, gestão, contratos e sustentabilidade na indústria baseada em florestas plantadas. In: CONGRESSO DA SOCIEDADE BRASILEIRA DE ECONOMIA E SOCIOLOGIA RURAL, 43, 2005, Ribeirão Preto. Anais... Brasília: SOBER, 2005b. p. 1-20.

GIL, A.C. Pesquisa em Economia. São Paulo: Atlas, 1991, 195 páginas.

HIGASHI, Y.H. Estratégias tecnológicas das empresas líderes na indústria brasileira de Papel. 1993. 196 p. Dissertação (Mestrado em Economia) Universidade Estadual de Campinas, Campinas, 1993.

HILGEMBERG, E.M.; BACHA, C.J.C. A evolução da indústria brasileira de celulose e sua atuação no mercado mundial. Análise Econômica, Porto Alegre, v. 19, n. 36, p. 67-92, 2001.

HILGEMBERG, E.M.; BACHA, C.J.C. A indústria brasileira de celulose de mercado e as pressões ambientais. Estudos Econômicos, São Paulo, v. 33, n. 1, p. 143-180, jan./mar. 2003.

JORGE, M.M. Competitividade da indústria de celulose. Campinas, 2001. Disponível em: < http://www.mct.gov.br/publi/Compet/nts_cel.pdf > . Acesso em: 21 mar. 2004.

LABATE, C.A. Bioengenharia florestal evoluiu com apoio de empresas. Visão Agrícola, Piracicaba, v. 2, n. 4, p. 120, jul./dez. 2005.

LEITE, N.B. Avanços da silvicultura brasileira são significativos. Visão Agrícola, Piracicaba, v. 2, n. 4, p. 120, jul./dez. 2005.

PARA empresários, Genolyptus consolida liderança do setor. Disponível em: $<$ http://www.mct.gov.br/comunicacao/textos/default.asp?cod_tipo $=1 \&$ cod_texto $=2004>$. Acesso em: 2 mar. 2006.

PIZZOL, S.J.S.; BACHA, C.J.C. Evolução, estrutura e desafios da indústria de celulose no Brasil. Preços Agrícolas, Piracicaba, v. 12, n. 137, p. 3-13, mar. 1998. 
SABATO, J.A.; MACKENZIE, M. Tecnologia e estrutura produtiva. São Paulo: Instituto de Pesquisas Tecnológicas, 1981 (Publicações Especiais, no 10).

SANJUAN, A.E.; BACHA, C.J.C. Avaliação da competitividade brasileira no mercado mundial de celulose. In: CONGRESSO DA SOCIEDADE BRASILEIRA DE ECONOMIA E SOCIOLOGIA RURAL, 41., 2003, Juiz de Fora. Anais... Brasília: SOBER, 2003. p. 1-15.

SARAIVA, F.; PERECIN, A.; GARCIA, M.F.; CAPO, P. Projeto de expansão Ripasa I marca nova fase de crescimento do grupo. O Papel, São Paulo, v. 67, n. 3, p. 64-79, jul. 2003.

SAVASTANO, R.M. Negócio rentável: é assim que a área florestal do setor passa a ser tratada no século XXI, perdendo a posição de simples fonte de matéria-prima da celulose. O Papel, São Paulo, v. 67, n. 3, p. 54-61, ago. 2001.

SEIXAS, F. Avanços tecnológicos e impasses na colheita florestal. Visão Agrícola, Piracicaba, v. 2, n. 4, p. 83-86, jul./dez. 2005.

SILVA, M.J. da. Fusões começam a redesenhar a estrutura mundial do setor de celulose e papel. Celulose e Papel, São Paulo, v. 16, n. 67, p. 34, 2000.

SILVA, M.L. da. Análise econométrica do mercado brasileiro de celulose e de papel e papelão. 1996. 120 p. Tese (Doutorado em Ciência Florestal) Universidade Federal de Viçosa, Viçosa, 1996.

TRENDS in world bleached chemical pulp production: 1990-2002. Disponível em: <http://www.aet.org/reports/market/aet_trends_2002.html>.Acesso em:16 set. 2006.

VALENÇA, A.C.V. A indústria de máquinas e equipamentos para o setor de celulose e papel. BNDES Setorial, Rio de Janeiro, n. 14, p. 93-110, set. 2001. Disponível em: <http://www.bndes.gov.br/conhecimento/bnset/set1405.pdf>. Acesso em: 25 fev. 2005. 